\title{
Representaciones de la Amazonia en cuatro libros de literatura testimonial del secuestro en Colombia*
}

\author{
Karen Lorena Romero Leal ${ }^{* *}$
}

Recibido: 25 de febrero de 2018

Evaluado: 12 de abril de 2018

Aceptado: 14 de mayo de 2018

\section{Resumen}

A partir del análisis de cuatro libros testimoniales del secuestro de personas del grupo de "los canjeables" se evidencia que la Amazonia es representada a través de dos de las imágenes recurrentes que sobre esta región se han emitido en la historia de su contacto con Occidente: un paraíso abudante en recursos naturales y un infierno verde. La primera de las imágenes responde al imaginario conservacionista de la naturaleza conceptualizada como medio ambiente, en el marco del discurso de la posibilidad de una crisis climática inminente. La segunda, que es la percepción de la Amazonia como un infierno que consume a quien cae en sus redes, se circunscribe a los espacios construidos por la guerrilla y que fueron experimentados con ellos. La representación de la Amazonia está en conexión con el drama que viven las víctimas del secuestro, cuya experiencia individual también se vive de manera grupal, así como transita desde las relaciones entre los seres humanos y de éstos con la naturaleza. Por tanto, la sensación apabulladora del dosel oscuro de la selva y de sus minúsculos, pero incómodos animales, se resalta como escenario del sufrimiento emocional y físico de los cautivos. Así, los libros

\footnotetext{
Artículo de investigación. Corresponde a una versión modificada del capítulo cuarto de la monografía de grado del pregrado en antropología de la autora. Su escritura se llevó a cabo en una estancia de investigación en la Universidad de Purdue, Estados Unidos, parcialmente financiada por la Dirección de Investigación de la Universidad Nacional de Colombia y el grupo de investigación de la Doctora Laura Zanotti, profesora del Departamento de Antropología de la Universidad de Purdue. La dirección del trabajo de grado estuvo a cargo del profesor Carlos Páramo y su edición fue apoyada por el literato Eduardo Huaytán Martínez. Citar como: Romero, K. (2018). Representaciones de la Amazonia en cuatro libros de literatura testimonial del secuestro en Colombia. Hallazgos, 15(30), 45-76. DOl: https://doi.org/10.15332/2422409X.4803

** Estudiante de la Maestría en Estudios Latinoamericanos de la Universidad de Leiden, Países Bajos. Socióloga y antropóloga de la Universidad Nacional de Colombia. ORCID: 0000-0002-2761-9554. Contacto: klromerol@unal.edu.co.
} 
analizados despliegan un discurso conformado por imaginarios sobre la Amazonia que se pliegan al proyecto social específico de los sectores más influyentes en los campos de la política y la economía en el país. Una de sus narrativas establece que tales territorios están totalmente disponibles para la inversión de capital luego de que sean liberados del dominio de los grupos rebeldes.

Palabras clave: representaciones del espacio, literatura testimonial, Amazonia, secuestro en Colombia 


\section{Representations of the Amazon in four kidnapping's testimonial-literature books in Colombia}

Received: february 25, 2018

Evaluated: april 12, 2018

Accepted: may 14, 2018

\section{Abstract}

From the analysis of four testimonial books about the kidnapping of people from the "Los Canjeables" group, it is evident that the Amazon is represented through two recurrent images that have been issued in this region during its history of contact with the West: a paradise abundant in natural resources and a green hell. The first of the images corresponds to the conservationist imaginary of nature conceptualized as an environment, within the discourse of the possibility of an imminent climate crisis. The second, the perception of the Amazon as a hell that devours those who fall into its net is limited to the spaces built by the guerrillas and experienced along with them. The representation of the Amazon is connected with the drama experienced by the victims of kidnapping, whose individual experience is also experienced collectively, as well as to the relationships between humans amongst themselves and the nature. Therefore, the overwhelming feeling of the dark canopy of the forest and its small, but unsettling animals, is highlighted as a scenario of the emotional and physical suffering of the hostages. Thus, the analyzed books display a discourse made up of imaginaries about the Amazon that are shaped by a specific social project of the most influential political and economic sectors in the country. One of its narratives is the availability of the territories for investment after their liberation from the domain of rebel groups.

Keywords: space representations, testimonial literature, Amazon, kidnapping in Colombia 


\section{Representações da Amazônia em quatro livros de literatura testemunhal do sequestro na Colômbia}

\section{RESUMO}

A partir da análise de quatro livros testemunhais do sequestro de pessoas do grupo "los canjeables", evidencia-se que a Amazônia é representada através de duas imagens recorrentes formadas sobre essa região na história do seu contato com o Ocidente: um paraíso abundante em recursos minerais e um inferno verde. A primeira das imagens corresponde ao imaginário conservacionista da natureza, conceitualizada como meio ambiente, no marco do discurso sobre a possibilidade de uma crise climática iminente. A segunda, a percepção da Amazônia como um inferno que consome quem cai em suas redes, circunscreve-se aos espaços construídos pela guerrilha e que foram experimentados com seus guerrilheiros. A representação da Amazônia está em conexão com o drama que vivem as vítimas de sequestros, as quais a experiência individual também se vive de maneira grupal, assim como transita entre a relação dos seres humanos e deles com a natureza. Por tanto, a sensação esmagadora do dossel escuro da selva e de seus minúsculos, porém incômodos animais, ressalta-se como cenário de sofrimento emocional e físico dos prisioneiros. Dessa forma, os livros analisados revelam um discurso configurado pelos imaginários sobre a Amazônia que se aproximam ao projeto social específico dos setores políticos e econômicos mais influentes no país. Uma dessas narrativas estabelece que tais territórios estão totalmente disponíveis para o investimento de capital, uma vez liberados do domínio de grupos rebeldes.

Palavras-chave: representações do espaço, literatura testemunhal, Amazônia, sequestro na Colômbia

Recebido: 25 de fevereiro de 2018

Avaliado: 12 de abril de 2018

Aceito: 14 de maio de 2018 


\section{INTRODUCCIÓN}

El secuestro ha estado ligado a la emergencia de las múltiples violencias que se han manifestado durante el largo conflicto armado interno en Colombia. Esta modalidad de presión ha sido utilizada por guerrilla, paramilitares, narcotraficantes y delincuencia común, con el fin, principalmente, de extorsionar las redes de apoyo de la persona retenida. El secuestro también ha sido utilizado para ejercer presión política y social y, por esa vía, alcanzar los objetivos de los actores armados. Por ejemplo, el uso del secuestro por parte de narcotraficantes, sobre todo del Cartel de Medellín, en los años ochenta y principios de los años noventa, tuvo como finalidad presionar la suspensión de la extradición de narcotraficantes a Estados Unidos a través de la privación de libertad de familiares de personas influyentes en la política colombiana.

Según Consuelo Hoyos (2014, p. 19) a finales de la década de los años ochenta se disparó el número de secuestros, y entre esa década y la de los años noventa este fenómeno creció, y Colombia llegó a ser el país con mayor ocurrencia del secuestro en el mundo. Aun así, el secuestro fue utilizado desde los primeros años en que surgieron las guerrillas, especialmente por parte de las FARC, en la década de los años sesenta, para financiar sus operaciones (2014, pp. 42-43). Hasta el 2008 los grupos guerrilleros habían cometido un 48,54 \% de los secuestros extorsivos, así: "FARC con 5.239 casos, ELN con 3.594, EPL con 626, ERP con 61 casos y ERG con 42. La delincuencia común cometió un 16,17 \% de los secuestros, las autodefensas fueron responsables del 4,07 \%, y un $17,57 \%$ no ha podido ser atribuido a ninguna organización criminal" (Dirección Antisecuestro y Antiextorsión, Policía Nacional, 2008, citado en Hoyos, 2014, p. 45).

Durante el gobierno del expresidente Andrés Pastrana y el primer periodo presidencial de Álvaro Uribe, en el marco del inicio, desarrollo y suspensión de los diálogos de paz del Caguán, la guerrilla de las FARC estableció una estrategia para presionar la realización de un intercambio humanitario que pusiera en libertad a guerrilleros encarcelados, a través del secuestro de un gran número de miembros del ejército y la policía, de personas ligadas al sistema político del país, e incluso de extranjeros que operaban programas de la lucha contra el narcotráfico. Este grupo fue llamado "los canjeables", en tanto las FARC los secuestraron para presionar un canje humanitario. Gran parte de ellos fueron llevados a los campamentos selváticos de las FARC, ubicados en la Amazonia colombiana, donde pasaron cinco o más años de cautiverio signados por el desplazamiento forzoso entre diversos puntos geográficos de la región amazónica. Luego del escape de unos pocos, o de la liberación, mediante rescate o gesto unilateral de la guerrilla - en la mayoría de los casos - un número importante víctimas escribieron y publicaron testimonios sobre su experiencia traumática de secuestro en libros que alcanzaron un amplio nivel de ventas (Romero, 2017). La mayoría de los testimonios fueron publicados después de 2009 por grupos editoriales de carácter multinacional, y por ende, su circulación alcanzó a otros países de América Latina, a Estados Unidos y a Europa. Se produjo, entonces, un auge de literatura testimonial, escrita directamente por los protagonistas de los episodios traumáticos, que estuvo ligado a 
la creación de otras producciones escritas y audiovisuales de consumo cultural como series, reportajes, películas, entre otras. De esta manera, las imágenes del secuestro han quedado en el recuerdo de las generaciones que vivieron la mediatización de las acciones de guerra de las Farc. Pese a su notable impacto, no existe todavía un trabajo académico publicado ${ }^{1}$ que analice el contenido y la forma de los libros de experiencias de secuestro, mucho menos que busque determinar cómo se representan allí la naturaleza y la población de la región amazónica. Por estas razones, la pregunta de investigación que guio el desarrollo del presente artículo fue: ¿cuáles son las representaciones del espacio y los habitantes amazónicos que se presentan en los testimonios del secuestro del grupo de "los canjeables"?

Para responder a esta pregunta se seleccionaron cuatro libros que dan testimonio de la experiencia del secuestro, dos de ellos escritos por personas que participaron en el sistema político colombiano, Alan Jara ( $E l$ mundo al revés, 2010) e Ingrid Bentancourt (No hay silencio que no termine, 2012). Además, se incluyó un libro escrito en conjunto por los estadounidenses - que estaban en el país apoyando la lucha contra el narcotráfico- Marc Gonsalves, Keith Stansell y Tom Howes (Lejos del infierno, 2009), con apoyo de Gary Brozek; y el texto de John Frank Pinchao, subintendente de la Policía (Mi

1 Precisamente mi monografía de grado para optar por el título de antropóloga (Romero, 2015), tiene como finalidad conocer el contexto de producción de este auge de literatura testimonial del secuestro y analizar las representaciones que los testigos establecen sobre s mismos como victimas, la guerrilla de las farc como victimarios, y sobre el espacio del secuestro. Un artículo fue publicado sobre las condiciones de producción del boom de literatura del secuestro en Colombia en la primera y segunda década del siglo presente. Ver Romero, 2017. fuga hacia la libertad, 2008). ${ }^{2}$ Es posible que la mayoría, sino todos estos libros, hayan sido escritos por escritores negros o fantasmas (ghostwriters) cuya participación sólo es admitida abiertamente por la publicación de Gonsalves, Stansell y Howes (2009). Por lo anterior es difícil rastrear la trayectoria profesional de estos escritores de oficio, pero es posible suponer que han estado expuestos a las representaciones sobre la Amazonia que circulan en los circuitos hegemónicos de producción discursiva. Por otro lado, se debe mencionar que los autores de los relatos lograron publicar sus relatos gracias al contexto de oportunidad de la política presidencial de Álvaro Uribe denominada "Seguridad Democrática" (2002-2010), que generó unanimidad de la opinión pública colombiana en torno a las FARC como principal enemigo interno de la nación (Romero, 2017). Su condición de víctimas del secuestro permitió que su experiencia de cautiverio fuera divulgada masivamente. A excepción de Ingrid Betancourt, quien ya había publicado dos libros sobre sus posiciones políticas, es posible decir que los autores de los libros analizados en este artículo no hacen parte de una clase letrada.

El presente artículo se divide en cuatro secciones. De tal modo, se dará cuenta de la metodología de investigación utilizada; los antecedentes conceptuales y empíricos del estudio; el análisis de los relatos

2 Los criterios de selección de los libros testimoniales fueron cuatro: 1) se seleccionaron textos realizados por los tres actores identificados: miembros de la fuerza pública, políticos, y extranjeros; en segundo lugar; 2) se incluyó la obra literaria de una mujer, para conocer sus particulares experiencias de cautiverio; 3 ) se consideraron obras escritas de manera individual y colectiva; y 4) se seleccionaron algunos relatos de personas que ya habían tenido un contacto antes de su cautiverio con la región de la amazonia-orinoquia como Alan Jara y John Fran Pinchao. 
testimoniales; y por último, se presentan las conclusiones.

\section{Metodología}

En primer lugar, es necesario señalar que el presenta trabajo es un análisis de cuatro libros testimoniales del secuestro en Colombia desde el lente de las ciencias sociales, campo de experticia de la autora. Como metodología de investigación se utilizó la aproximación cualitativa al análisis crítico del discurso, basado en los aportes de Teun Van Dijk (Pardo, 2007), así como la teoría del núcleo central de las representaciones sociales propuesta por Tania Rodríguez (2007). Para esta autora, las representaciones se componen de un núcleo central y unos elementos periféricos. Para identificar los núcleos centrales de las representaciones es necesario encontrar los thematas o temas persistentes en el discurso y de este modo, jerarquizar los contenidos de las representaciones.

Para poder analizar las representaciones sociales, en su contenido y estructura, Tania Rodríguez (2007, pp. 181-183) propone una serie de indicadores discursivos que permiten establecer jerarquías entre los contenidos de las representaciones, a saber: las figuras retóricas - metáforas, metonimias, entre otras - las repeticiones y los énfasis, las relaciones de causalidad, las fuentes de autoridad, la atribución de estatus ontológico a representaciones naturalizadas, las asociaciones emocionales y conceptuales. Así pues, el principal interés por la forma del texto serán sus aspectos semánticos y pragmáticos. También se hallaron los rasgos textuales comunes a través del estudio de los temas sobre los que hay mayor enunciación y emotividad. Para encontrar esos temas principales y reiterativos se siguió el establecimiento de los themata a través del estudio de formas de nominación de los capítulos, valoración emotiva de los eventos, frecuencia de los temas y sus formas de representación. Junto a ello, se tuvieron en cuenta los componentes paratextuales de los cuatro libros escogidos.

El proceso de categorización se realizó, en primer lugar, de forma deductiva, es decir, a partir de los conceptos trabajados en el marco conceptual y de las hipótesis planteadas, incluyendo las categorías que plantea Pardo como el tema, las acciones, los actores, y las formas de clasificación cultural. En segundo lugar, al avanzar en el análisis de los datos, emergieron nuevas categorías que reflejaban de manera más fidedigna la problemática estudiada, de tal manera se continuó una categorización inductiva.

\section{Antecedentes: REPRESENTACIONES SOCIALES $Y$ LA Amazonia}

El sociólogo francés Emile Durkheim estableció la categoría de "representaciones colectivas" para distinguirlas de las conceptualizaciones producidas individualmente. Esto implica que las representaciones colectivas son más que la sola reunión de las representaciones individuales, en tanto tienen identidad propia y proveen el material simbólico para clasificar el mundo. De esta manera, las categorías de clasificación son hechos sociales que existen antes del individuo en el mundo social. Como para el autor los contenidos de la conciencia colectiva forman un sistema de creencias compartidas, que está por fuera del individuo 
y lo configuran socialmente, los aportes de Durkheim han sido criticados porque se centran más en la conservación y reproducción de un aparato conceptual en el conjunto social y dejan de lado los mecanismos de transformación ideológica (Vera, 2002). Como se verá, las categorías para clasificar la vida social claramente están tomadas del conjunto de creencias y valores socialmente compartidos en un marco espacio-temporal, pero estas mismas categorizaciones son particulares de la experiencia personal, al punto de que los productos de clasificación cultural, como los testimonios, pueden ser contradictorios entre sí.

Uno de los principales conceptos de este ejercicio investigativo es el de representación social. Myriam Jimeno en su artículo sobre las novelas de la violencia en Colombia, conceptualiza representaciones sociales como "construcciones simbólicas para aprehender la realidad, que están fabricadas con valores, creencias, principios, metáforas y estereotipos vigentes en la sociedad en la cual nacen", que sirven como "sistemas de clasificación e interpretación" de eventos, personas, acciones y afectos (Jimeno, 2012, pp. 296). Es necesario anotar, además, que las representaciones sociales sobre el espacio y los habitantes amazónicos contenidos en las obras testimoniales han surgido a partir de un proceso de escritura que, de acuerdo con Mesnard (2010), está caracterizado por la reelaboración de los saberes y las emociones, incluido el trauma vivido, a partir de la experiencia y el contacto directo con otros actores.

A través del análisis de los imaginarios contenidos en el campo científico del orientalismo inglés, francés y estadounidense, Said en su obra Orientalismo (2008) da cuenta de cómo el desarrollo de conocimiento científico está permeado por las relaciones de poder desiguales que están presentes en la relación entre el científico y el objeto de estudio. En un principio definido como exótico y extraño, luego como conocido y comprensible, Oriente, como región geográfica, entra al campo de la ciencia occidental para que su realidad sea domesticada y con ello, controlada. Además, las imágenes orientales que se construyen desde la objetivación científica sirven como insumo para la creación de obras literarias que reproducen y resignifican las representaciones sociales de Oriente en otros circuitos de la vida cultural de los países interesados por imponerse políticamente en esta región.

De esta manera, Occidente constituye su otredad en Oriente, y a la vez se crea a sí mismo por oposición a los rasgos sociales y geográficos con los que caracteriza la parte oriental del mundo. La racionalidad moderna y la primacía moral que de ésta dicen obtener, sirven como justificación para que los estados imperiales se impongan sobre regiones y poblaciones que consideran incapaces de gobernarse a sí mismas. El orientalismo, dice Said (2008), reemplaza a Oriente, porque se enuncia como la verdad sobre éste, siendo más bien un discurso que lo representa a través de imaginarios que crea y difunde.

La construcción de representaciones sobre un espacio geográfico considerado "otro" en oposición a un "nosotros", también es materia de indagación en el libro El revés de la nación de la antropóloga Margarita Serje (2005), quien analiza un importante número de estudios regionales para entender cómo desde la ciencia y el Estado-nación se constituyen representaciones sobre las zonas de frontera interna de Colombia, como lo son 
la mayor parte de la Orinoquia y Amazonia. Para la autora, las regiones "otras" de la nación, es decir, aquellos territorios que han tenido un desarrollo sociopolítico y económico diferenciado de las áreas cuyo devenir histórico ha estado ligado a la presencia evidente de la capacidad monopolizadora del poder del Estado - como la región andina y parte de la región caribe - han sido objeto de construcción de relatos, basados principalmente en dos imágenes focales: la posesión de riquezas inexploradas y la violencia constitutiva. Ésta última quiere decir que las dinámicas conflictivas que se viven en estos lugares se perciben como esenciales en su construcción territorial e integración a la nación colombiana.

Estas narrativas han alimentado las representaciones que la sociedad colombiana, en su conjunto, ha constituido sobre las zonas de frontera, sirviendo como argumentos explicativos de su realidad. De tal manera que estos espacios se han construido en la academia, en la opinión pública y en las instituciones del Estado-nación como diametralmente opuestas al deber ser de la organización moderna de los ámbitos político y social presentes en las áreas centrales del país. Lo anterior genera la idea de que las regiones fronterizas han sufrido una ausencia histórica del Estado y, por ende, no han podido consolidarse como espacios modernos donde se produce y circula el capital. Pero para Margarita Serje las zonas de frontera han sido construidas como un necesario "otro" del país modernizado, puesto que a éste último le permite legitimarse como el modelo social que puede lograr organizar, de la mejor manera, los territorios y las poblaciones. A su vez, el capitalismo necesita de territorios no integrados cabalmente al sistema económico, para emprender sus formas más depredadoras de explotación de recursos y personas, puesto que el capitalismo extractivo sigue viéndose como irremediablemente necesario para la producción de grandes capitales. Los Estados-nación que se encuentran en una posición no dominante en el sistema mundo han admitido que la inserción del sistema económico dominante se dé allí a partir de la extracción continua de recursos naturales en los márgenes de sus países, sitios que no están integrados totalmente a la nación.

Para Ana Pizarro, crítica literaria chilena, la Amazonía es una construcción discursiva, puesto que esta región, "tal como la percibimos desde su descubrimiento por los ojos del hombre occidental, (es) la historia de los discursos que la han construido en diferentes momentos históricos" (2009, p. 28). Los imaginarios de la selva amazónica constantemente la han representado a través de la diferenciación entre civilización y barbarie, así como entre paraíso e infierno. En un primer momento, los conquistadores españoles que se internaron en la selva produjeron imaginarios plagados de criaturas fantásticas; posteriormente, surgió la visión de los misioneros religiosos relativa a la condición salvaje de la población nativa, que podía ser redimida a través de su conversión al cristianismo. A finales de la colonia y principios de la era republicana, la Amazonia se empezó a ver como una fuente inagotable de recursos naturales, por parte de los exploradores y viajeros ilustrados, pero también como un espacio deshabitado y carente de cultura, que debía ser poblado con extranjeros virtuosos.

Para entender las representaciones que a finales del siglo $\mathrm{xIx} y$ en el siglo $\mathrm{xx}$ ha 
producido la clase dirigente y la opinión pública colombiana sobre la Amazonia, se pueden analizar las investigaciones del antropólogo Álvaro Santoyo, quien realizó su monografía de grado sobre las representaciones sociales de la Amazonia por parte de la elite colombiana entre los años 1875 y 1910, y posteriormente se detuvo en las representaciones de esta región contenidas en la prensa escrita en el periodo de 1900-1975. Como resultado del primer ejercicio académico, Santoyo (2004) determinó que importantes personajes de la vida política, económica y científica del país, como lo fueron Rafael Reyes y Agustín Codazzi, recorrieron parte de la región amazónica y a partir de allí produjeron reflexiones sobre su naturaleza agreste y su población indígena, que consideraban como primitivos e irracionales. Dentro de estas reflexiones, que llevan insertas representaciones sociales sobre el paisaje, se encuentran proyectos para domesticar este territorio, natural y culturalmente.

En lo que atañe a las representaciones de la Amazonia en el siglo xx contenidas en la prensa colombiana, el autor reconoce tres grandes objetos de representaciones, que son: la naturaleza, los procesos de colonización y la población indígena. Desde un determinismo geográfico que permanece a principios del siglo $x x$, se pasa a considerar la Amazonia como un espacio de naturaleza virgen que puede ser sometida a procesos de cambio natural y cultural. De ahí que muchos escritores influyentes en la vida nacional, como Rafael Reyes quien fue inversionista de la explotación quinera y cauchera a finales del siglo xIx, propusieran diversidad de proyectos, que compartían la idea de la necesidad de poblar esta región con población venida de afuera, que la colonizara y pudiera establecer un cultura nacional, en tanto sus habitantes nativos no podían emprender procesos de modernización. Sin embargo, luego de la masiva llegada de colonos después del periodo de La violencia y la instauración de enclaves empresariales de explotación de recursos naturales, se problematiza la situación social de la región al concebirse al colono como contrario a esos proyectos económicos, siendo protagonista, entonces, de un conflicto social.

La Amazonia se ha constituido como una frontera o límite espacial entre diversos ecosistemas, culturas y naciones, pero también, como lo argumenta Carlos Páramo, el territorio que incluye la Amazonia y la Orinoquia se ha visto como "un hito que separa al salvaje del civilizado, a lo manso de lo bravo, al delito de la ley, al animal del humano, a la cultura de la naturaleza, al mito de la historia" (2012, pp. 209-210). Así es que perdura un gran mito occidental sobre la selva que se basa en "la idea de que Occidente solo puede definirse por oposición simbólica a la dupla selva-salvajismo que este mismo ha concebido" (2012, p. 210). Empero tales oposiciones son fluidas, y pueden variar de acuerdo al momento histórico en que se establecen, y a quien las enuncia. Lo anterior se puede ejemplificar en la consideración actual de las poblaciones indígenas amazónicas como buenos salvajes que cuidan el medio ambiente mucho mejor que la civilización occidental, que se precia de tener un complejo tecnológico y científico cada vez más avanzado. La valoración positiva del nativo ecológico varió desde una consideración negativa de los pobladores nativos como primitivos e incultos. Así mismo, una sola persona puede encarnar dos 
dualidades aparentemente excluyentes entre sí, es el caso del tipo social del trickster, que encarna la ambigüedad y la paradoja (2012, p. 216), condiciones para ser capaz de traspasar las fronteras.

Un concepto útil para entender las representaciones espaciales de la Amazonia, como área homogénea, es el de "geografías imaginadas", utilizado por Edward Said (2008) al analizar los estudios de área sobre Oriente. Por otro lado, las categorías de "frontera", "frontera interna", "periferia", son para Margarita Serje cuestionables, puesto que esconden tras de sí un mito de la frontera, que moviliza la metáfora de lo salvaje y de regiones que están en proceso de construcción sociopolítica y económica (2005, p. 248), es decir, que no han llegado a normalizarse.

El libro El revés de la nación de la antropóloga Margarita Serje evoca la existencia de unas zonas de frontera que deben su existencia no a la imposibilidad de integrarse política y económicamente a una nación que aspira ser modernizada, sino a que los centros de la economía capitalista necesitan de los recursos - naturales y humanos- que se encuentran en zonas que se conocen como indomables y violentas. De esta manera, se puede seguir alimentando la irracional racionalidad de la transformación capitalista de recursos que no pueden acabarse, puesto que siempre se hallarán nuevas reservas. Por su parte, Guarín establece que "la Amazonia se configuró como una frontera no solamente territorial, sino también representativa y simbólica, que tan solo desde finales del siglo xix empezó a ser incorporada en la visión geoestratégica del mundo. En efecto, la apropiación territorial de la Amazonia se realizaría por medios simbólicos y representacionales, incluso antes que territoriales y administrativos" (Guarín, 2012, p. 166).

Lo dicho hasta el momento es indispensable para entender las representaciones de la Amazonia en las obras de literatura testimonial del secuestro analizadas en este trabajo, ya que, como productos culturales, dialogan con las narrativas no solo de la tradición literaria sobre la selva colombiana y latinoamericana, sino con los discursos que han circulado en la esfera pública durante todo el siglo $\mathrm{xx}$, emitidos principalmente por agentes que detentan un nivel considerable de poder político, económico y por ende, de poder simbólico. Aun así, es importante tener en cuenta que La Vorágine de José Eustacio Rivera, publicada en 1924, y Perdido en el Amazonas, de Germán Castro Caycedo, del año 1978, constituyen referentes de la literatura colombiana sobre la Amazonia que han calado en los imaginarios colectivos del conjunto social, que no necesariamente constituyen élites letradas.

Por un lado, Rivera con la novela La Vorágine pretendió denunciar las condiciones infames que enfrentaron los trabajadores colombianos en la selva amazónica durante el auge del caucho a principios del siglo $\mathrm{xx}^{3}{ }^{3}$

3 El afán extractivista en toda la Panamazonia coincide con la penetración de agentes externos cuya acción violenta produjo consecuencias desastrosas sobre todo para los pueblos nativos como las que resultaron de la incursión europea en el continente americano a partir del siglo xvi. Así pues, la explotación cauchera en la Amazonia colombiana significó la desestructuración social de las poblaciones nativas cuyos territorios fueron invadidos y cuyos sujetos, sin excepción de edad, género o estatus, fueron esclavizados como mano de obra descartable (Pineda, 2000). La historia de la Amazonia no sería la misma desde la explotación del caucho por agentes externos a la región, pues se siguió perpetuando el orden de trabajo semiesclavista de la población indígena, que siguió ocupando un lugar subordinado en los subsiguientes ciclos extractivos, y por ende, sus prácticas culturales han continuado estando bajo constante amenaza. 
quienes se vieron sometidos a vejámenes de parte de caucheros peruanos y colombianos que impusieron todo un régimen de terror en la Amazonia colombiana. Por otro lado, Perdido en el Amazonas (1978) es una crónica narrada en primera persona por el hermano de Julián Gil, su protagonista. Gil era un exmilitar que decidió internarse en la selva para emprender una empresa comercial, pero que desapareció de manera abrupta al ser raptado por un grupo de indígenas no contactados en el área del río Cahuinarí, departamento del Amazonas. Las historias de Arturo Cova y Julián Gil tienen en común que ambos son hombres del interior del país, que cuentan con cierto capital educativo y deciden colonizar los territorios nacionales - frontera interna del país durante gran parte del siglo $x x$ - para escapar de la justicia, en el caso de Cova, o para explorar nuevas oportunidades para hacer dinero como es el propósito de Gil. Ambos, además, terminan quedándose en la Amazonia por potencias que sus escritores describen como más fuertes que la voluntad personal. En La Vorágine esta potencia se identifica con un destino fatalista, mientras que en el libro de Castro Caycedo, se manifiesta a través de un progresivo encantamiento de Gil, que primero se enamora de una mujer indígena y luego, ambiciona controlar toda una población nativa para fundar un emporio económico en medio de la selva. Así pues, las historias de colonización que fueron publicadas con cincuenta años de diferencia, coinciden en la manifestación violenta del ímpetu colonizador de la selva amazónica y de su población nativa. Aunque esa violencia se dirija esencialmente a domesticar la selva con fines extractivos, irremediablemente ese interés economicista se traduce en relaciones sociales conflictivas que son expresadas en estas obras a través de la representación de la Amazonia como espacio hostil, a pesar de su evidente abundancia de recursos naturales (Ortiz, 2007; Jaramillo, 2016). Los libros analizados en este artículo hacen eco del imaginario ambivalente de la Amazonia como espacio cuya disponibilidad de naturaleza conduce a la puesta en escena de intereses egoístas que se disputan su posesión a través de cruentas guerras.

\section{AnÁlisis}

Philippe Mesnard hace un llamado para no olvidar que el testimonio es una representación del trauma vivido y por ende, "en ningún caso hay que confundir, salvo que se borre la diferencia entre texto y mundo, la escritura del trauma y el trauma, ya que la primera es la expresión codificada del segundo. Y su 'sorprendente literalidad' no es una nueva producción del hecho, sino su reproducción por medio de la representación" (2010, p. 406). Por otro lado, para Alexander, "la representación del trauma depende de construir un armazón convincente de clasificación cultural" (2003, p. 94). Este proceso simbólico, que consiste en contar una nueva narración, "es contingente, altamente contestado y a veces altamente polarizado", así como sus transformaciones dependen de la relación que establezca con los discursos y prácticas institucionales. El argumento de Mesnard que diferencia el texto y el mundo contradice la idea de Clifford Geertz del mundo cultural como un texto $\mathrm{y}$, por ende, susceptible a ser interpretado. La vida en la selva, como se verá a continuación, fue un ejercicio interpretativo por parte de los cautivos para poder sacar provecho del conocimiento del espacio en que se encontraban. A su vez, es posible 
cuestionar que el testimonio sea una simple reproducción de un evento traumático, pues para nosotros es una re-construcción que responde a unas determinadas expectativas sociales $\mathrm{y}$, por tanto, constituye un producto cultural.

Este apartado se divide en los siguientes núcleos centrales de las representaciones sobre la Amazonia: del revés de la nación a la barbarie, población amazónica, y de selva indómita a medio ambiente encantado.

\section{DEL REVÉS DE LA NACIÓN}

\section{A LA BARBARIE}

La metáfora a la que recurre Serje (2005) donde los espacios de frontera constituyen el revés del centro nacional da pie para pensar que la nación es una hoja de papel que tiene un lado frontal, el visible y el ideal; y otro lado, que está en el reverso, donde está lo invisibilizado, lo abandonado, y sujeto a unas lógicas no contempladas por la razón capitalista. Sin embargo, las metáforas a las que recurren los exsecuestrados en sus libros testimoniales profundizan radicalmente la diferencia entre el mundo de sus vidas y el mundo que tuvieron que enfrentar cuando estuvieron secuestrados en la selva. No lo toman como las dos caras de una misma moneda, sino como dos mundos trascendentalmente diferenciados. Por ejemplo, el nombre del libro de Alan Jara, El mundo al revés, evoca constantemente que el secuestro fue una experiencia paradójica donde el mundo de "nosotros" se encontraba patas arriba, y emergía el mundo "otro" y de los "otros", que en este caso eran los guerrilleros. En ese mundo al revés emergía toda clase de vivencias incomprensibles de precariedad, imposición del más fuerte a través de las armas, así como falta de solidaridad entre los mismos secuestrados, lazos de amistad entre víctimas y victimarios, gestos de bondad por parte de los secuestradores, entre otras paradojas, que Alan Jara recuerda con lucidez. Seguramente estos hechos paradójicos hicieron que gran parte de los secuestrados cambiaran el modo como veían el mundo, pues muchos de ellos se prometieron a sí mismos cambiar su estilo de vida si obtenían su libertad.

Las personas exsecuestradas que más expresan una diferenciación total entre el mundo de sus vidas cotidianas por fuera de la selva y el mundo de la guerrilla en la selva son los tres estadounidenses, exmarines que trabajaban en la identificación de los cultivos de coca en diferentes zonas del país a través de vuelos aéreos. El reconocimiento de la situación en que se encontraban fue más complicado porque dos de ellos no sabían hablar español con suficiencia. De esta manera, ellos mejoraron su español escuchando a los guerrilleros y a sus compañeros de cautiverio. A pesar de ello, la experiencia de secuestro estuvo llena de hechos extraños o que rayaban en lo absurdo, a las que los estadounidenses se referían como surrealistas, palabra que, es necesario resaltar, también usa Ingrid Betancourt.

Tanto como nosotros nos cansábamos de oír '¿Quién sabe?', estoy seguro de que ellos se preguntaban por qué usábamos tan a menudo palabras como "extravagante" y "surrealista". Estar caminando por la selva-pasando con frecuencia por los campos de coca que antes habíamos reportado desde el aire-, con un montón de terroristas chupa-colombinas, come-dulces, con cerebros lavados, había atrofiado 
nuestro vocabulario, así que recurríamos a nuestras manidas palabras de siempre. (Gonsalves, et.al, 2009, p. 77).

En la anterior cita, Marc Gonsalves señala que su vocabulario se había reducido como consecuencia del choque cultural de permanecer forzosamente en un espacio "otro" y tener que relacionarse con personas cuyo comportamiento no consideraba racional. Justamente por ello, hacía uso de sus "manidas palabras de siempre" para dar cuenta del estado de sorpresa hacia los nuevos eventos que enfrentaba. Como el mundo social es construido por los agentes sociales a través de sus prácticas y discursos, la situación traumática del secuestro tenía que ser contada coherentemente y de hecho, como una estrategia de supervivencia este episodio tenía que ser explicado a través del lenguaje en el marco de la cultura. Como este suceso dramático es difícil de explicar, se le concibe como la realidad volcada. ${ }^{4}$ Tal experiencia se convierte en acontecimiento, tal como lo propone Jacques Rancière, puesto que fue narrada en el marco del testimonio. Como acontecimiento que se sale del horizonte cultural de las víctimas del secuestro, esta vivencia es clasificada en diferentes partes de sus relatos como "absurda", "paradójica", "extraña”, "fuera de lugar" y "surrealista". Sobre todo, lo que se califica con estas cualidades son hechos particulares de la vida en cautiverio, resultados de la acción de guerrilleros, otros compañeros de secuestro y hasta de la manifestación de la naturaleza. También se refiere al contexto liminal de incertidumbre que viven los

4 De acuerdo con Jaramillo, Alejo Carpentier presenta la selva amazónica como un espacio de "acumulación y simulacro, donde las cosas no son lo que parecen ser y por tanto, donde uno puede también perderse" (2016, p. xxxv) rehenes, puesto que según Alan Jara "la situación era paradójica: era el mundo al revés, pues temíamos que nos mataran las balas de las Fuerzas Militares, que en cambio debía protegernos" (2010, p. 86).

El uso de tropos como "el mundo al revés" (Jara, 2010) y "sueño al revés" (Gonsalves, 2009, p. 119) generalmente se encuentra en la primera parte de los libros donde se describe el tránsito hacia la vida en cautiverio, es decir, en el proceso de reconocimiento y aceptación de la privación de libertad. Entonces, se pasa de tener una vida aparentemente autónoma y controlada por el individuo, a una situación de represión de la independencia individual para tomar decisiones y actuar conforme a los planes de vida previos del retenido. ${ }^{5}$

Así mismo, es posible decir que se pasa de un estado cultural a un estado natural, donde las convenciones de comportamiento establecidas llegan a ser moldeables, puesto que lo importante era sobrevivir en un campo social desconocido. Sin embargo, el secuestro no anula la experiencia cultural, pues los recursos simbólicos pueden ser moldeados para poderse adaptar a nuevas situaciones sociales. Como bien lo dice

5 El entendimiento de la condición del secuestro luego del transcurso del tiempo conllevó a que los retenidos desplegaran distintos tipos de estrategias para hacer frente a la situación. De modo que esta situación inexplicable fue tramitada, en algunas ocasiones, a través del humor, que resultó del reconocimiento de eventos inconcebibles. Esta fue una de las estrategias usadas por Alan Jara y varios militares y policías, cuyas vidas, en muchos de los casos, no habían sido planeadas totalmente y cuyas posiciones en el mundo social se percibían como el resultado de las pocas oportunidades disponibles, generalmente posibilitadas por un ser superior con control sobre los recursos escasos como el dios cristiano o el gobierno, que muchas veces establece relaciones personalizadas a través de la clientela. Empero, en algunos casos esta actitud fue fuertemente criticada por personas cuyas posiciones sociales responden a trayectorias de vida calculadas, construidas por una enorme inversión de recursos simbólicos de sus padres y mentores. 
Keith Stansell, “sabía que en algún momento iba a tener que cavar bien profundo, de modo que me dije que lo mejor era examinarme interiormente y ver con qué contaba" (2009, p. 131), pues como sujetos racionales debían echar mano de conocimientos adquiridos previamente. Pero la adaptación individual podía ser fortalecida a través de la conjunción de las habilidades de varios secuestrados, como en el caso de los tres estadounidenses. Tom Howes se refiere así a su estrategia mancomunada:

Comprendí que todos teníamos habilidades diferentes y necesarias para triunfar. Lo que teníamos que hacer ahora era concentrar nuestro pensamiento en cómo utilizar esas destrezas para sobrevivir al cautiverio. Estábamos aplicando viejas destrezas en un entorno nuevo. Eso iba a tomar tiempo y requería un proceso de ensayo y error. (2009, p. 127).

Respecto al constante traslado a la que se vio obligada al principio de su cautiverio, Betancourt anota que "era obvio que cada vez nos adentrábamos más en la selva y cada paso nos alejaba de la civilización" (2010, p. 113). Es decir que ella utiliza, como los demás autores, el término civilización para referirse a un lugar poblado con facilidades urbanas. De esta manera, estar en medio de la selva, fuera al interior de los campamentos guerrilleros o en un área habitada por personas, era para ellos estar lejos o incluso, afuera de la civilización.

Para Pinchao, quien trabajó un tiempo en Mitú, ni siquiera los poblados de la Amazonia colombiana eran lugares civilizados, ya que no contaban con todos los servicios que una ciudad del interior colombiano pudiera tener. A continuación, se presenta un aparte en el que plasma su primera percepción de la Amazonia cuando llega a Mitú:

Satena, la única empresa de transporte de pasajeros que vuela a los territorios nacionales, como se les llama a las zonas apartadas y olvidadas de nuestro país.

En el trayecto solo se observaba un interminable tapete verde, nuestra selva colombiana. Cuando nos acercamos, desde el aire se divisaba un río, y a orillas de este había un pequeño pueblo: era la ciudad de Mitú. Al descender, sentí que había hecho un viaje a través del tiempo. Cuando el avión aterrizó, levantó una inmensa polvareda roja porque la pista de aterrizaje no estaba pavimentada.

Luego, al bajar del avión sentí un calor pegajoso que me envolvía, era el bochorno que acostumbra hacer en estas regiones selváticas de clima húmedo. Observé casas humildes, hechas en madera, y la mayoría de la población era indígena. La población tenía el aspecto de un pueblo agobiado por la pobreza y el olvido. ${ }^{6}(2008$, p. 27).

De la misma manera que Howes (2009, p. 67) que siente que pasó de la Era de la Informática a la Edad de Piedra, ${ }^{7}$ Pinchao

6 Las cursivas no están en el original y corresponde a la autora del presente artículo.

7 La idea del regreso a un estado primitivo y antediluviano puede rastrearse también en obras de literatura clásica como El corazón de las tinieblas de Joseph Conrad y El mundo perdido de Conan Doyle. Si se tiene en cuenta la tradición literaria sobre la selva amazónica, las obras de de Alfredo Rangel, José Eustacio Rivera y Euclides da Cunha presentan a la Amazonia como un espacio sometido a fuerzas premodernas que necesitan ser sometidas por los estados 
considera que el tiempo se detuvo en la Amazonia, incluso en la capital de uno de sus departamentos, debido a que no encontró allí los desarrollos en infraestructura de otras ciudades colombianas. Además, Pinchao relaciona la noción de zona apartada, que implica tanto estar lejos geográfica como simbólicamente, con abandono estatal, y por ende, con pobreza de la población. Así pues, el olvido se manifiesta en que el Estado colombiano no es capaz de garantizar que la población de estas regiones viva sin carencias; en cambio, si el gobierno nacional les prestara más atención, podría dejar de ser "un pueblo agobiado". Con referencia al lugar donde el avión ocupado por los tres contratistas estadounidenses debía aterrizar de emergencia, uno de ellos lo describe como una "montaña dejada a la mano de Dios en la selva colombiana" (2009, p. 17). Entonces, el abandono de estas zonas no del todo pobladas y de difícil acceso sólo es contrarrestado por la acción divina.

Sin embargo, que la Amazonia colombiana fuera un lugar olvidado por el gobierno y la sociedad colombiana, en general, no significaba que las regiones amazónicas de otros países vecinos no pudieran desarrollarse económicamente y contar con presencia gubernamental, que en este caso se materializa en la base militar. Pinchao argumenta lo anterior a partir de una historia narrada por un amigo suyo:

Me contó que pasaba de Yavaraté (Colombia) a Yavaraté (Brasil) y que había mucho contraste entre las dos poblaciones: mientras que en Colombia se veía un pueblo agobiado por la pobreza, al otro

nacionales para que la región pueda constituir un devenir dentro de la Modernidad. lado se observaba una bonita base militar y una ciudad sin tanta pobreza. ${ }^{8}$ (Pinchao, 2008, p. 71).

La anterior imagen de la Amazonia brasilera en comparación con la colombiana responde a los procesos diferenciados de desarrollo económico de estas regiones, que fueron estimulados por los gobiernos centrales especialmente a partir de los años cincuenta y sesenta (Ortiz, 2007). Sin duda, fue en la región amazónica brasilera donde estas dinámicas de integración condujeron a una modernización más evidente, puesto que allí se ejecutaron de manera más efectiva planes gubernamentales como la construcción de carreteras en medio de la selva, los programas de colonización y la promoción del crecimiento económico y poblacional. Este proyecto de modernización había sido reclamado por Euclides da Cunha en sus escritos sobre la región a finales del siglo XIx. Así mismo, Rivera se opone a los intereses extractivistas de tipo imperial y llama al gobierno colombiano a hacer presencia en esas zonas fronterizas que Pinchao también considera abandonadas. De modo que Pinchao como funcionario público - antes de ser secuestrado hacía parte en las Fuerzas Militares - y los expolíticos Betancourt y Jara continúan ese clamor por integrar de manera eficiente la Amazonia a las dinámicas productivas del centro del país. Todos los libros analizados presentan a las FARC como el mayor impedimento al desarrollo, pues controlaban la economía a través de la imposición del cultivo de coca a los campesinos para la producción de cocaína. Ese carácter cíclico de la economía extractiva en la Amazonia la ha mantenido en un estado

8 Las cursivas no están en el original y corresponde a la autora del presente artículo. 
barbárico, en tanto su territorio era controlado por un grupo guerrillero sanguinario que presumía ser el mismo Estado.

\section{REPRESENTACIÓN DE LA POBLACIÓN AMAZÓNICA}

Cuando iba en una de las tantas marchas por la selva que la guerrilla obligaba hacer a sus rehenes para trasladarlos de un campamento a otro, Alan Jara le pidió a uno de sus captores, cuyos rasgos físicos le indicaban que era indígena, que le diera algún consejo para poder mejorar su desempeño físico. Este guerrillero le recomendó poner unas hojas que le dio debajo de su lengua y al interior de su oído. De un momento a otro, Jara se sintió mejor y por eso le preguntó cuál era el árbol que tenía ese efecto terapéutico, a lo que el indígena le respondió modestamente que la acción de las hojas no se debía al árbol de donde las había arrancado, sino que sirvieron como entretención para que dejara de tener la boca abierta y no respirara por ahí. Esta situación permite reconocer que los exsecuestrados esperan que los indígenas tengan un saber práctico de su entorno, especialmente en lo relacionado con plantas medicinales. Aunque en este caso no se demostró sus conocimientos, sí se logra percibir que se reconoce la capacidad de observación y recursividad de los nativos.

Una vez más las habilidades de los indígenas dentro de la selva son valoradas en los relatos analizados. Cuando Betancourt no puede caminar en otra de las marchas por la selva, pues al parecer estaba padeciendo de hepatitis, dos guerrilleros la cargan en su espalda. Sin embargo, uno de ellos es indígena y justamente es quien demuestra tener mayor fuerza corporal, pero también abnegación y cuidado con ella. Adicionalmente, se comporta de manera humilde con uno de sus compañeros que no es para nada amable con él, desplegando no solo una superioridad física, sino, según Betancourt, mayor humanidad. A partir del recuento de este evento, se ve que Betancourt valora la obediencia sin réplica y el sacrificio desprendido. La anterior perspectiva revela la naturalización de las relaciones de poder coloniales, puesto que todavía en el siglo xxI los indígenas sirven como cargueros de individuos que, aunque víctimas, sus vidas resultan siendo más importantes para la guerrilla que la de sus combatientes, especialmente los lugareños que han ingresado al grupo armado sin apostarle a la adquisición de posiciones de mayor poder en la organización.

Si bien Pinchao desconfiaba del género humano, puesto que cuestionaba por igual el comportamiento de sus captores y el de sus compañeros de secuestro, es cierto también que mantiene en su libro el imaginario de los nativos amazónicos como buenos salvajes. El tropo del buen salvaje expuesto por Rousseau y utilizado en las categorías de etnicidad de la disciplina antropológica que han privilegiado la coherencia cultural de los grupos indígenas en torno a prácticas comunes como el uso de una lengua, y la vida comunal en un sólo territorio, ha devenido en los últimos años en la construcción discursiva del nativo ecológico como lo han anotado académicos como Astrid Ulloa. La imagen del nativo ecológico se conecta con el creciente interés del movimiento ambientalista por encontrar un modelo de vida armónico con la naturaleza, en el que su sujeto ideal se caracteriza por preservar 
y conocer profundamente los elementos naturales. La expectativa de Pinchao por reconocer en los indígenas amazónicos a nativos ecológicos se puede evidenciar en el siguiente fragmento:

Les preguntábamos a los indígenas si existía alguna planta con la que se pudiera hacer repelente para evitar las picaduras, pero esos indígenas eran indígenas que habían crecido en los pueblos y de la selva sabían muy poco, así que no nos daban solución. Por eso los llamábamos 'indios gomelos'. (2008, p. 116).

Según esta cita, ser indígena y vivir fuera de la selva, sin conocer de ella y del uso de sus recursos, corresponde a una contradicción y por ende, se los tilda de gomelos, a pesar de llamarlos "indios", palabra que continua teniendo una carga despectiva en todo el territorio colombiano. Una contradicción que debe ser remediada a partir de reclasificar a estos nativos en un nivel socioeconómico mayor, pero conservando el sentido paradójico de la existencia de un indígena que presume estar en mejores condiciones que sus coterráneos, caracterizados generalmente como pobres y poco presuntuosos.

La región amazónica no solo es caracterizada con pobreza y abandono estatal, como se vio anteriormente, sino también por el imperio de la represión fariana, a través del uso forzado de la fuerza de trabajo, y la cooperación directa e indirecta de la población con sus actividades. Esto se evidencia en la descripción de un establecimiento que proveía a este grupo de objetos indispensables para la actividad militar:
[...] Finalmente los guerrilleros nos guiaron a una edificación donde había un grupo de personas sentadas en unos bancos. El olor a curtiembre pesaba en el ambiente. Paramos por un minuto. Era claro para nosotros que los guerrilleros querían que viéramos cómo eran de emprendedoras estas personas. Estaban haciendo los chalecos de cuero que los guerrilleros usaban. En vez de impresionarme, el episodio tuvo el efecto contrario en mí. Estas personas eran claramente esclavas de las FARC. Les pagarían una miseria, si es que les pagaban por hacerles el trabajo. Ninguno de los trabajadores nos miró. Debieron haber oído que tres americanos pasarían: no mirar, no tocar. A la salida del pueblo pasamos cerca del cementerio. Aun los que estaban muertos sabían que era mejor no mirar mientras pasábamos a su lado. (Howes, Stansell y Gonsalves, 2009, p. 92).

La posibilidad de ser testigo directo de las acciones de los actores armados, que muchos ligan con complicidad, ha sido evitada a lo largo del conflicto armado colombiano por la población civil a través del hecho de "no mirar". Cuando no se ve, no se actúa, y no se reclama por tanto alguna acción que contrarreste la presencia guerrillera. Los autores presentan a los pobladores como seres que están bajo el yugo de la guerrilla, sin tener ningún margen de maniobra ni poder de decisión. El siguiente aparte escrito en el libro Mi fuga afirma que los habitantes de las regiones por donde pasan están acostumbrados a la guerrilla, y afirman que esta situación cambiaría en tanto la fuerza pública tomara posesión de esos lugares. Una vez más se ve que para Pinchao la guerrilla 
podría desaparecer si hubiera más presencia de la fuerza pública, de tal modo que la forma de integrar estos territorios a la nación es principalmente militar y de inversión económica:

A lo lejos vimos pasar una lancha de personas civiles que llevaban canastas de cerveza y provisiones, me imagino que para alguna tienda, y por eso nos ordenaron agacharnos, para que no nos vieran. Claro que a los guerrilleros sí los vieron. Parece que por esos lugares es común que transiten sin ninguna dificultad, porque por allí no hay presencia de la fuerza pública. (2008, p. 140).

Ingrid Betancourt y Alan Jara también recalcan la dificultad de los pobladores para denunciar los actos de las FARC, por tanto, su traslado por la región, en poblados y lugares de habitación campesinos, se asegura por un cierto pacto de silencio obligado por la organización armada. Sin embargo, esa no es la única manera como la población amazónica responde a la presencia del grupo armado. Jara, usando la noción de civilización, da cuenta de la relación entre economía local de carácter ilegal con cierta libertad de movimiento de la guerrilla.

La noche del 24 de diciembre de 2004 la pasamos en ese extraño lugar. A lo lejos alcanzábamos muy tenuemente a escuchar música. Con seguridad provenía de alguna "chacra", porque habíamos visto bastantes cultivos de coca en el área. En todo caso, era como sentir de cerca la civilización, lo que nos dio más nostalgia todavía. (Jara, 2010, p. 197).

Como los exsecuestrados no mantienen un contacto prolongado con la población civil en su cautiverio, las representaciones de los habitantes amazónicos no guerrilleros se reduce a menciones vagas que los relacionan con sus percepciones del espacio amazónico y del conflicto armado en la región. Es decir, con una concepción del espacio no habitado de la Amazonia como un espacio de naturaleza selvática y, por ende, prístino, pero con el protagonismo o mejor, imposición del poder de las FARC en las dinámicas sociales de la zona por donde se desplazan.

\section{De selva indómita a MEdio AMBIENTE ENCANTADO}

Germán Palacio señala que desde los años ochenta el discurso sobre la naturaleza, especialmente con relación a las regiones periféricas del mundo, depende de la perspectiva conservacionista del medio ambiente que percibe los espacios silvestres no como áreas rezagadas del movimiento desarrollista, sino como reductos cuyos recursos biodiversos pueden salvar a la humanidad de su potencial extinción. De esta manera, para el autor se produce una naturaleza ambientalizada, donde también "la mercantilización de la naturaleza llega a su punto más alto" (2001, p. 28). La domesticación de estos espacios remanentes, en relación directa con el estado del capitalismo global, le correspondería ahora a entes no-gubernamentales supeditados a organizaciones financieras y compañías de alcance internacional, mientras que los Estados nacionales pierden incidencia territorial, así pues estos espacios empiezan a ser considerados como patrimonio de la humanidad, es decir, se declara una apropiación global más que nacional.

Como se ha visto, enfrentar una situación nueva y en este caso, extrema, implica 
recurrir a referentes simbólicos previamente adquiridos. El conocimiento previo que los estadounidenses tenían acerca de zonas con naturaleza abundante estaba constituido por los contenidos emitidos en los canales National Geographic o Animal Planet, caracterizados por la recreación estética de espacios de difícil acceso. Marc Gonsalves se refiere a ello de la siguiente manera:

Siempre me habían gustado los programas de televisión sobre la naturaleza y, de repente, me encontré dentro de uno. Si no fuera por las circunstancias, me habría encantado. La variedad de micos era superior a la de cualquier zoológico; la mayoría de ellos eran distintas clases de micos araña. Como nuestros captores, ellos también parecían muy interesados en los chicos nuevos de la selva y se colgaban de los árboles para mirarnos con sus enormes ojos. (p. 60).

Al contrario de muchas obras literarias y trabajos académicos donde se adscribe a la Amazonia colombiana una violencia constitutiva (Serje, 2005), el paisaje amazónico para Pinchao es lo que le permite olvidarse de su condición de secuestrado. Así lo expresa al recordar cuando es obligado por primera vez a penetrar la selva: "Todo eso era novedoso para muchos de nosotros, ver tantos animales, y en medio de la tragedia uno se alcanzaba a maravillar con tanta belleza" (2008, p. 58).

Los animales mismos son expresión de libertad pues están en su hábitat sin ninguna fuerza externa que les impida seguir con su vida. Esta metáfora ilustra bastante bien lo que los animales amazónicos les inspiraban a los secuestrados:
En uno de esos días de la llegada se metió un sapo en el encierro. Era muy grande y gordo, y querían sacarlo. Cuando estaba cerca de la puerta, el muy tontico cogió hacia el otro lado y terminó dándole la vuelta a todo el encierro. Llegó exhausto nuevamente a la salida, pero logró su libertad. Recuerdo esto como un acto simbólico de libertad que todos celebramos aplaudiendo y gritando vivas. (Pinchao, 2005, p. 78).

Alan Jara (2010) describe profusamente la relación fraternal de los cautivos con los animales selváticos y domésticos. A partir de su relato es posible darse cuenta que una de las actividades favoritas de los secuestrados, especialmente de los miembros de la Fuerza Pública, era cuidar un sinnúmero de especies animales como gallinas, loros, gatos, perros, ratones, zarigüeyas, entre otras. Cuidar un ser, para ellos, indefenso, ya que también adoptaban cachorros o animales enfermos, les servía para no perder su humanidad. Era pues una manera de dar y recibir cariño sin sentirse en algún momento decepcionado por alguna actitud humana controvertible, puesto que los animales representaban para ellos criaturas cuyo comportamiento responde a lógicas naturales y por ende, no era intencional o egoísta.

En el libro de Jara (2010), la naturaleza no se presenta ni desconocida ni apremiante, sino más bien compleja, pero posible de aprehender. Esto se debe tanto a su crianza y vivencia en la Orinoquia, como a su convivencia con personas que han sido entrenadas para trabajar en condiciones selváticas, como lo son los militares y policías secuestrados. Además de lo anterior, Jara siempre está dispuesto a aprender y reconocer que 
no lo conoce todo, a pesar de su experiencia académica. De tal manera que en cautiverio mantiene un deseo de experimentar y re-aprender desde otra perspectiva lo que ya le habían enseñado. Lo siguiente ilustra este modo de actuar:

Quedamos asombrados del tamaño del animal, de su cabeza, colmillos, garras y el pelaje característico: amarillo con rayas negras. No nos quedó ninguna duda: jera un tigre! Sentí que en la escuela me habían engañado cuando dijeron que en América no había tigres. Lo único que falta es que cuando salga y cuente lo del tigre no me crean, pensé. Varios pidieron que les regalaran un colmillo o las garras. Para asegurarme de que me creyeran, pedí un pedazo de piel para mostrarlo en la libertad, pero no quisieron dármelo. Cuando nos preguntaron si queríamos comer tigre, de inmediato levanté la mano y aunque no todos lo hicieron, nos trajeron una buena ración para que la probáramos. Me pareció una carne muy dura y algo picante, pero valía la pena comerla. (2010, p. 158).

Betancourt (2012) considera a su vez que si ella no estuviera secuestrada, podría disfrutar las maravillas naturales con las que se encuentra y sin duda alguna, compartiría este tipo de experiencia con sus seres queridos. Además, Pinchao (2008) da a conocer que ella le presenta un bosquejo de un proyecto político para las zonas de frontera, específicamente para el Magdalena Medio, donde se combinaría el uso de medios de transporte con un alto desarrollo tecnológico como un tren de alta velocidad con la protección del medio ambiente. De esta manera, en múltiples ocasiones, Betancourt se presenta a sí misma como políticamente correcta en cuanto presenta un discurso conservacionista, y en varios momentos presenta al grupo guerrillero como devastador de los recursos naturales, como cuando sanciona la cacería de un tigre que andaba rondando el campamento en el que se encontraba.

Aún así los proyectos de intervención económica en la región no son tan comunes en las narrativas que presentan los testigos, y más bien prevalece el imaginario de la naturaleza selvática como original, en tanto se ha conservado sin ninguna modificación humana, tal como se evidencia en las palabras de Pinchao, quien sobre una fuente hídrica anota que "estábamos en el sitio donde el agua era pura de verdad" (2008, pp. 92-93). Junto a su carácter prístino, los espacios selváticos -que ellos revelan múltiples - también son presentados con una estética digna de admirar. Jara lo evidencia cuando describe dos de los muchos lugares que observa: "de repente llegamos a un sitio donde se unían dos ríos y el paisaje era realmente hermoso" (2010, p. 113) $\mathrm{y}$ "estaba impresionado de ver la inmensidad del cielo azul, totalmente despejado y sin árboles que lo ocultaran" (p. 132). Por el contrario, los espacios habitados o socialmente construidos son mostrados en muchas ocasiones como anómalos y problemáticos por el accionar pernicioso de las FARC y la economía cocalera. Así que cuando los elementos naturales se representan en su conexión con una selva intocada, éstos son caracterizados estéticamente y revelan un genuino interés por entender su lógica, a pesar de la inexperiencia y la ignorancia. Sin duda alguna, se manifiesta un proceso 
de adaptación forzado, pero resiliente, a la vida en cautiverio en medio de la selva. Sin embargo, la relación que se construye con el espacio de prisión es problemática debido al estado omnipresente de los guerrilleros de las FARC como mediadores entre el espacio natural intacto y el espacio social de enclaustramiento.

La naturaleza selvática no solo se presenta como un oasis que se caracteriza por su belleza y originalidad, sino como un paraíso que encarna una dimensión metafísica. Como cualquier otro espacio social, la selva es construida simbólicamente por quienes la habitan forzosamente. De esta manera, se proyectan allí los conocimientos ambientales, las percepciones estéticas, pero también los problemas, deseos y expectativas de los cautivos. Como se vio anteriormente, los animales de la selva son mostrados con una naturaleza bondadosa que se opone a la corrupción humana de los secuestradores y de los compañeros de cautiverio, quienes también son egoístas, desleales, interesados y agresivos. Este apartado busca mostrar que la selva es vista también como un territorio encantado, donde se vehiculan mensajes místicos.

En el transcurso de una marcha por la selva, Keith Stansell encuentra en el lugar donde está descansando una motivación para seguir adelante:

Pestañeé para aclarar la vista y, justo en mi cara, en un pequeño claro de luna, había una flor blanca. Estaba a unos quince centímetros y era tan pequeña que parecía el detalle de una fotografía de Ansel Adams. Al principio pensé que estaba alucinando. Habíamos caminado durante las últimas veinticuatro horas, de las cuales pasé un buen rato mirando al piso. Todo lo que había visto era tierra, piedras y hojas secas. ¿De dónde diablos salía esta flor?

No soy sentimental, pero ver esa flor me produjo algo. Pensé en mi familia y en lo que pasarían sin mí. Me dije que saldría de allí, que no había otra opción. Perdí a mi mamá a los catorce años y sabía lo que significaba perder un padre a temprana edad. No quería que mis hijos sintieran la misma angustia. Esa flor me dio la energía que necesitaba para levantarme. De hecho, sentía tanto alivio que comencé a cuestionar mi estado mental. ¿Qué otra razón tangible, distinta a esta flor, tenía yo para sentir tanta esperanza? Cómo me habría gustado haberla arrancado y llevado conmigo, aunque de cierta forma lo hice. De ahí en adelante, siempre encontré la manera de regresar a ese lugar donde, por un breve instante, supe que sobreviviría. (2009, p. 51).

Horas después Stansell se siente mal físicamente tras otro exigente recorrido y se arrepiente de no haber llevado la flor consigo. A pesar de describirse a sí mismo como poco sentimental, siente que esa flor blanca es un objeto muy particular que le recuerda que aún hay esperanza cuando se cree que todo está perdido. A pesar de no llevarla consigo, este pequeño elemento le recuerda que debe sobrevivir para volver a ver a su familia. Los prisioneros en la selva, a través de los meses y los años, van estableciendo una relación diferente con los elementos de su entorno natural. Si al principio de su cautiverio la selva les parecía un espacio irreconocible y difícil de clasificar, la experiencia 
vivida en contra de su voluntad los lleva a entender la lógica de la selva y a interpretar sus signos a partir de su memoria, sus deseos, sus sueños y expectativas.

La misma situación le sucede a Marc Gonsalves, quien ve cómo las alas de una mariposa están compuestas por unos puntos rosados como el color de las muñecas Barbie, el color favorito de su hija. Aquello inmediatamente le hace recordarla, y por eso la bautiza "la mariposa de Destiney". Luego afirma: "cada vez que la viera después de esto, me llenaría de una cantidad de emociones mezcladas. Pensaría en mi hija. Esa mariposa era una señal. Tenía que serlo. Supe que había un significado especial en que esa mariposa volara junto a mí justo cuando estaba dudando de si podría superar esta prueba" (p. 121). Una vez más un diminuto elemento de la naturaleza sirve de motivación para no desistir en la dura situación de cautiverio.

En estos relatos se construyen metáforas en las cuales objetos animados e inanimados de la naturaleza tienen vida propia y representan la acción o la idea que el autor quiere comunicar de una manera gráfica. Sin embargo, la animación de la selva y sus componentes no siempre es resultado de una estrategia manifiesta para atraer diferentes tipos de público. También son usados recursos simbólicos que son propios del constructo social de gente que ha vivido en el campo, para quienes los animales y las plantas son referentes simbólicos de la vida social. Esto puede ser observado en el hecho de que un político, miembros de la Fuerza Pública e incluso, guerrilleros crean que la presencia o la acción de un ave señale un evento futuro.

A continuación se presentan dos fragmentos en los que Jara da a conocer el progresivo encantamiento de su perspectiva respecto a la selva. Aunque al principio criticaba que sus compañeros, generalmente militares que crecieron en el campo, establecieran enlaces entre un elemento o suceso de la naturaleza con un significado, en especial en una relación de causa-efecto, llamándolos "agüeros", luego se encuentra a sí mismo pidiendo a las fuerzas de la naturaleza la revelación de noticias optimistas para él. Este cambio en el modo de conocer y reconocer la realidad se centra en los signos que revelen eventos relativos a la vida, la muerte y la libertad. Ceder ante esta nueva manera de ver las cosas no implica, otra vez, deshacerse de sus referentes simbólicos previos, y por eso se da un ejercicio de nominación usando valores conocidos como el vínculo entre aves voladoras y libertad.

Habían llevado entre Murillo, Donato, Consuelo y el coronel las gallinitas que nos quedaban. Una se 'enculecó' y coincidió con que la guerrilla encontró dos huevos de pava. Eran de color verde como el de la tela de una mesa de billar; yo nunca los había visto y nos dijeron que si poníamos a la gallina culeca a empollarlos. Aceptamos y la gallinita muy juiciosa los empolló durante tres semanas y una madrugada nacieron. Siempre me parecía increíble el milagro de la vida y dije que ese era un mensaje de la naturaleza, que definitivamente era el año de la libertad. Como las crías son siempre solo dos, un macho y una hembra, entonces propuse bautizarlas 'Freedom' al macho - 'libertad' en inglés- y 'Svoboda' a la hembra, también 'libertad', pero en ruso.

Estábamos felices con Freedom y Svoboda y decíamos que cuando crecieran 
les daríamos la libertad, pero una madrugada una anaconda se metió al nido y se las comió.

- ¿Y ese también es un mensaje de la naturaleza? -preguntó Donato.

-Nooo, es la ley de la selva - contesté bastante apesadumbrado. (Jara, 2010, p. 224).

Si la anterior cita demuestra la negociación social de los signos de acuerdo a cómo se desarrollan los eventos, que implica, además, un cierto nivel de agencia por parte de los secuestrados, que luego de mucho tiempo de cautiverio deciden establecer unas rutinas, como por ejemplo ser responsables de animales domésticos; en el siguiente fragmento es más evidente el cariz mágico que toma la acción de un águila como mensajera de una noticias.

[...] mientras jugaba una partida de ajedrez con Géchem, llegó un águila grandísima y sobrevoló nuestro campamento muy lentamente.

-El águila de la libertad - dijeron, como susurrando, Murillo y Donato.

Yo, que no creo en agüeros, mentalmente rogaba que se posara en el árbol de mi carpa, pero pasó sobre él y silenciosa se posó en el árbol del cambuche de Géchem. Nos miramos entre todos nosotros.

-Vamos, aguilita, párese también en mi árbol [...]-dijo Murillo.

El águila, tan lentamente como había llegado, se fue y nos quedamos todos en silencio. Era la primera vez que esto ocurría en todo el tiempo del secuestro. Al minuto llegó Cuarenta y Cinco y le dimos la novedad del águila que se había ido, pensando más en el almuerzo que en la libertad.

-Alístese, Géchem, que se va, salimos ya - dijo Cuarenta y Cinco". (Jara, 2010, p. 262).

El proceso de significación del anterior evento no se basa en la simple correlación entre el signo - ave- y el símbolo - libertad - , sino que el referente actúa por sí mismo para ser expresión de una liberación próxima, es decir, el signo actúa. Sin duda alguna, la significación de los elementos naturales son también una proyección de los deseos más profundos de los cautivos, y de este modo, "los signos se ven investidos de significados que encuentra su sentido dentro de la narrativa misma". ${ }^{9}$

Aunque muchas veces se revela como positiva, en medio de la selva también se pueden encontrar fuerzas negativas que abruman la experiencia de los relatores. El episodio onírico que presenta Pinchao ejemplifica lo anterior: "Una noche en la que me encontraba durmiendo tuve una pesadilla. Se trataba de una gran sombra negra que salía de los árboles y se abalanzaba sobre mí. En medio del sueño grité, me desperté angustiado y pensé que era una premonición de alguna tragedia" (2008, p. 59). ${ }^{10}$ Por otro lado, el encantamiento de la selva a través de espíritus se produce a través de la manifestación de lo conocido, como en el caso de Betancourt quien en un momento, con una alta carga espiritual, siente la presencia del alma de su padre que acababa de morir. Su presencia

9 Esta conclusión surgió a partir del valioso comentario del par evaluador del presente artículo.

10 Las cursivas no están en el original y corresponde a la autora del presente artículo. 
se manifiesta a partir del cambio del estado del clima y la disponibilidad de luz solar.

La situación del secuestro en los campamentos guerrilleros hace que los autores caractericen el lugar donde se hallan como hostil y opresor. Por ejemplo, Keith Stanse11 afirma que "éramos conscientes de estar justo en el centro de un mierdero" (2009, p. 34), cuando relata que había comprendido la angustiante situación en la que se encontraba. Por su parte, Tom Howes llama territorio enemigo al entorno natural de su cautiverio:

El bosque estaba lleno de cosas que podían morder, picar o perforar nuestra carne. Cada vez que tambaléabamos y alargábamos una mano para sostenernos, agarrábamos un bejuco, un árbol o un matorral lleno de espinas. Estábamos en territorio enemigo, en todo el sentido de la palabra. (p. 48).

Este carácter hostil de la selva hace eco de obras como La Vorágine en donde la naturaleza selvática amenaza la vida de quienes buscan dominarla o al menos, subsistir en medio de ella sin conocerla. Así mismo, en el libro Infierno verde de Alberto Rangel, la naturaleza es representada como una entidad independiente que se defiende de los intereses expoliadores de los nuevos migrantes, que llegan a la Amazonia buscando riqueza fácil (Domingues, 2003). Presentar, entonces, la selva como territorio enemigo refuerza la idea de que ese territorio aún no ha sido conquistado. De acuerdo con Ortiz (2007) y Jaramillo (2016), la idea de la naturaleza amazónica como "inhumana", o por lo menos, no amable con los seres humanos, que pone de presente La Vorágine, es una crítica del modo en que se desarrollaba la actividad extractiva del caucho, pues estaba envuelta en relaciones de poder desiguales y explotación de la mano de obra, incluidos los nativos. Aquí, entonces, la selva también encarna las dinámicas violentas impulsadas por la guerrilla, quienes de una $u$ otra forma ejercen dominio sobre un territorio que, aunque pertenece a la nación, no responde a su lógica gubernamental ni en términos sociales o ecológicos.

Ingrid Betancourt, al referirse a la partida de uno de sus guardias con el que había establecido una buena relación, escribe que "su ida me afligió mucho. Tal vez porque, a pesar de todo lo que nos separaba, yo había encontrado en él un corazón sincero. Sabía que en esta selva abominable, había que desapegarse de todo para evitar un mayor sufrimiento" (2010, p. 225). ${ }^{11}$ El carácter negativo impuesto a la selva se debe eminentemente al episodio doloroso que vive la autora. Esto se evidencia al contrastar la anterior narración con la descripción que ella hace del entorno tres páginas atrás, y donde su contacto con Ferney, el guardia que luego es retirado, influye en su bienestar:

Era un lindo día de diciembre, la estación seca en la selva y la mejor de todo el año. Una brisa acariciaba las palmas, se colaba por entre el follaje hasta llegar a nosotros y nos aportaba una sensación de calma que nos era poco común.

Me había instalado fuera de la jaula, a la sombra, y tejía con aplicación, pues quería terminar el rosario ese mismo día. Ferney estaba de guardia y le pedí que me cortara

11 Las cursivas no están en el original y corresponde a la autora del presente artículo. 
unos pedazos de madera para formar el crucifijo de mi rosario. (2010, p. 222).

El ejercicio de representar la selva a través del lenguaje no es solo el establecimiento de categorías que describan el ambiente circundante. La naturaleza selvática es usada para insertar la situación individual del secuestro en el testimonio. Así, los autores toman elementos naturales para crear narrativas coherentes imbuidas en tramas de significado con un alto potencial de eficacia simbólica. Por ejemplo, la flor que le recuerda a Marc Gonsalves el significado de su vida o el cóndor que escenifica la subsiguiente liberación del también político Jorge Géchem, de acuerdo con Jara (2010).

En varias ocasiones se acusa a la naturaleza de estar implicada en el malestar psicológico y físico de los secuestrados. Los fragmentos que se presentan a continuación evidencian que describir el drama del cautiverio implica establecer un telón de fondo que sea consonante con la escena traumática:

El cielo se cargó de gruesas nubes negras. Una vez más, el mal tiempo se ponía de parte de la guerrilla. Ya no se oía el motor de la marrana. ${ }^{12}$ Las muchachas me pasaron un plástico negro. (Betancourt, 2010, p. 113).

En la anterior cita, Ingrid Betancourt identifica las condiciones adversas del clima con las dificultades que enfrenta un helicóptero de la Fuerza Aérea que rastrea los movimientos de la guerrilla a través de la selva. El mal tiempo impide el buen funcionamiento de la tecnología de punta que está desplegando el gobierno nacional para

12 Los guerrilleros utilizaban la palabra marrana para referirse a un avión de la Fuerza Aérea. encontrar a los prisioneros y una vez más, las herramientas y estrategias simples e improvisadas a la que recurren los guerrilleros de las FARc tienen éxito en un mundo que no se rige por los estándares de la modernidad. Esto último se distingue en el siguiente fragmento en el que se enuncia una comunión entre el posicionamiento agresivo de la guerrilla y las condiciones agrestes del territorio por el que se mueven:

Nos presionaban, nos decían que teníamos que callarnos o que de lo contrario nos matarían. Sentíamos punzadas en los pies y nos salieron ampollas. La luna se elevó sobre los árboles y la temperatura bajó como una plomada. Tropezábamos en las tinieblas sin una luz que nos guiara. En algún momento, ya bien entrada la noche y al borde del agotamiento, nos detuvimos en una rocosa ribera. El sonido del agua ahogó el de los insectos y demás vida silvestre. Nos sentamos y nos enjuagamos los pies ensangrentados. El agua fría hizo arder la carne viva de nuestras ampollas. Unos cuantos guerrilleros se desvistieron y caminaron por el agua sin preocupación. (Howes, 2009, p. 47).

Howes subraya los modos diferenciados en que los secuestrados, gran parte de ellos presentes por primera vez en el territorio amazónico - especialmente, los políticos y los tres contratistas estadounidenses - y los combatientes guerrilleros perciben y se relacionan con la naturaleza selvática. Mientras que los prisioneros sufrían a la par física y emocionalmente, los guerrilleros vivían resignados a esa vida itinerante en "el monte" y sus condiciones físicas estaban totalmente adaptadas a vivir en estado de alerta 
permanente y transitar o permanecer en zonas no tan apropiadas para una subsistencia moderna.

Daniel Ruiz anota que "la fusión entre guerrillas y selva refuerza la idea de una topografía moral y representa a la selva como un lugar inherentemente peligroso, dotada de una suerte de poder y voluntad que mantiene a la gente privada de su libertad" (2015, p. 9). Esta imagen puede ser percibida en la representación de las condiciones del secuestro de "los canjeables" en los medios de comunicación. Además se ve que, como en el romanticismo, los narradores producen una identificación entre su estado psíquico y físico y las condiciones del entorno natural. Al decir de Gonsalves, "mi estado mental era como el paisaje: picos agudos bañados por la luz del sol y un valle profundo sumido en las sombras"' (2009, p. 62). Por ende, para Gonsalves, su estado emocional y psicológico se mimetiza en los rasgos y transformaciones del entorno natural. Tal estrategia narrativa evitaría también que el lector olvide que la confusión y el desánimo que describen los testigos es consecuencia directa de su condición de víctimas en un territorio al que han estado obligados a habitar en contra de su fuerza y su voluntad. Entonces, la descripción del secuestro como situación hostil que desestructura bruscamente el devenir de sus vidas implica que el espacio de confinamiento no sea aceptado inmediatamente como un lugar adecuado de habitación, sino todo lo contrario, un espacio enemigo dominado por el grupo victimario.

Es interesante el relato de Ingrid Betancourt con relación a uno de los intentos de fuga que emprende, en el que la naturaleza pasa de ser algo externo y condicionante, a convertirse en una serie de agentes que le posibilitan a la escritora ser ella misma, y así, escapar de su vida desgraciada:

Ahí mismo mi relación con ese mundo de la noche empezaba a cambiar. Avanzaba más fácilmente, mis manos reaccionaban con mayor agilidad y $\mathrm{mi}$ cuerpo aprendía a anticipar más rápido los accidentes del terreno. La sensación de horror comenzaba a disiparse. El medio que me rodeaba ya no me era totalmente hostil. Percibía esos arboles, esas palmas, esos helechos, esa maleza trepadora como un posible refugio.

La angustia que me producía mi situación, el hecho de estar empapada, de tener las manos y los dedos ensangrentados, de estar cubierta de barro, de no saber a donde ir, todo eso parecía menos importante. Podía sobrevivir. Debía seguir caminando, seguir en movimiento, alejarme. Al amanecer volverían a iniciar la persecución. Más en el calor de la acción, me repetía 'soy libre', y mi voz me hacía compañía.

Imperceptiblemente, la selva se hizo más familiar, pasando del mundo oscuro y plano de los ciegos, a un terreno de relieves monocromos. Las formas se hicieron más definidas y finalmente los colores volvieron a tomar posesión del universo: era el alba.

Quería encontrar un desnivel en el terreno que me permitiera envolverme en mi gran plástico negro y taparme con hojas. En pocos minutos, la selva pasó del azul grisáceo al verde.

La selva parecía tan cerrada. Ni un solo ruido, ni un solo movimiento. El 
tiempo había quedado suspendido. (2010, p. 27).

Luego de que su relación con la selva se modificara, Betancourt no solo vincula su estado emocional o corporal, sino que se presenta unificada con la naturaleza. Así mismo es un espacio donde ella sufre una transformación de su carácter y posición frente a la vida. Esto es lo que relata unos párrafos más adelante:

Ahí estaba el río. Yo lo veía correr, encabritado, arrastrando con furia árboles enteros que parecían pedir ayuda. El agua bajando a borbotones me acobardó. Había, no obstante, que lanzarse al agua y dejarse llevar. Ese era el precio de la salvación.

Aquellos troncos que giraban en el agua y desaparecían para salir a flote más adelante, con sus ramas extendidas hacia el cielo, eran yo misma. Me veía sumergida en ese mar de barro. (Betancourt, 2010, p. 28). ${ }^{13}$

Generalmente los campamentos guerrilleros, donde están ubicados los estrechos sitios de confinamiento, son objeto de descripciones negativas, por las condiciones de hacinamiento e insalubridad, pero también por las situaciones de estrés y violencia que experimentan. Por su parte, las narraciones de los momentos en que a los rehenes se les permite salir de las "jaulas" para realizar actividades de dispersión en ambientes abiertos contienen descriptores positivos. Bañarse en un río o tomar el sol sobre unas rocas son espacios y tiempos liberadores. Con respecto a las marchas forzosas en medio de la selva, los exsecuestrados expresan

13 Las cursivas no están en el original y corresponde a la autora del presente artículo. sentimientos ambivalentes puesto que dejan de estar enclaustrados generalmente sin recibir la luz directa del sol, pero ellos o sus compañeros estaban encadenados y todos eran sometidos a jornadas extenuantes. Es precisamente en la narración de los intentos de escape cuando la naturaleza se ve como aliada y no como enemiga. A diferencia de lo anotado por Ruiz (2015, p. 3) donde para las comunidades indígenas y negras del Bajo Atrato en el Pacífico colombiano, "el monte es lo opuesto al espacio trabajado y como tal es un ámbito peligroso que escapa al control directo de los humanos", la selva que los exsecuestrados narran es un espacio de oportunidad, de tránsito constituido por muchos obstáculos peligrosos pero superables. Así pues, es posible determinar que se construye discursivamente la oposición entre los campamentos guerrilleros como lugares donde reina el caos, la violencia y el terror, y la selva como lugar de escape, de salvación, de liberación, y de transformación. Otras oposiciones se anexan a la anterior dicotomía: quietud vs movimiento; oscuridad vs luz, áreas de acción vs áreas de pasividad; zonas de represión vs zonas de toma de decisiones; espacios de enclaustramiento vs espacios de libertad; y lugares de terror vs lugares de esperanza.

Como Alan Jara y los tres estadounidenses no intentan escaparse, este manejo discursivo no se presenta en sus relatos. Por el contrario, la narración de la fuga con la que Pinchao consigue su libertad es la mejor evidencia de que sí es posible superar los rigores que impone la naturaleza amazónica. Ser miembro de la policía le da herramientas a Pinchao para sobrevivir en la selva, pero también el aprendizaje adquirido luego de vivir durante más de ocho años 
de cautiverio. Jara explica la razón de estos nuevos aprendizajes diciendo que "teniendo tanto tiempo libre, solíamos observar las cosas con más detalle" (2010, p. 231).

Así pues, en la última parte del texto, donde describe la fuga y su preparación para emprenderla, Pinchao demuestra que ha sido capaz de desentrañar las lógicas de la selva. Cuando ha superado obstáculos que no le permitían desafiar los retos de la naturaleza, como por ejemplo, aprender a nadar, se siente listo para enfrentarla y por ende, dominarla. Pinchao, entonces, representa al humano que puede imponerse sobre la selva. Es, sin duda alguna, la antítesis de Arturo Cova de La Vorágine o Julián Gil de Perdido en el Amazonas, quienes sucumben ante la selva traicionera. Luego de una batalla de dieciocho días contra el hambre, la hipotermia, las criaturas selváticas, y las tierras anegadas, Pinchao vuelve a la "civilización" llevando el mensaje de que la Amazonia no es una frontera inescrutable, que solo resta una condición para ser explotada económicamente y por ende, ser integrada al Estado-nación, que es la eliminación física y moral de las FARc. En la siguiente cita el autor delinea un posible proyecto económico para la región: la mercantilización de la selva primigenia para el beneficio de los habitantes de la Amazonia:

Cuando estuve allí pensaba en lo hermoso que es nuestro país y que se podría crear un turismo ecológico que dejara mucha ganancia para beneficiar a los pobladores de aquellas regiones con tantas necesidades, pero que desgraciadamente son territorios dominados por la guerrilla de las FARC. (2008, p. 153). ${ }^{14}$

14 Las cursivas no están en el original y corresponde a la autora del presente artículo.

\section{Conclusiones}

Mientras que en múltiples ocasiones la naturaleza selvática se percibe como bella y buena, en tanto los elementos que la componen se comportan coherente e inocentemente, el espacio social amazónico es centro de las críticas de los autores pues presentan a los poblados como lugares atrasados con innumerables problemáticas sociales, donde pulula la pobreza y el olvido gubernamental. Sin embargo, se enuncia que tal situación podría ser transformada al erradicarse por completo a las FARC, y puedan ser implantadas economías que tomen ventaja de los recursos naturales de la región.

En la medida que los relatos fluyen, la región amazónica deja de ser concebida como el espacio otro, como el revés de la nación, puesto que se ha entendido a partir de la experiencia personal, y resulta ser más comprensible y por ende, controlable. Como estrategia discursiva, la selva es caracterizada como oscura e incómoda, pero siempre cuando está relacionada con la presencia y acciones de la guerrilla. A su vez, la población civil es representada como totalmente dominada por los designios de las FARC, es decir, sin posibilidad de resistir y posicionarse como sujetos autónomos. En cuanto a la población indígena, se los percibe como unos seres primigenios bondadosos, pasivos, pero con un gran conocimiento natural que puede ser aplicado. No encontramos que se les reconozca como personajes místicos, sino más bien como personas con unas prácticas culturales que están en decadencia. De ahí que se les valore por sus saberes sobre la selva, que como se vio, se reconocen como resultado de la observación sistemática y la organización rigurosa 
de la información recolectada. Es decir, una búsqueda de regularidades con un método.

Entonces, si se exterminan los salvajes, condición más de la guerrilla que de los indígenas, la Amazonia dejaría de ser menos salvaje, más domesticada, más viable para su explotación y control del espacio. Esto se lograría, sin duda alguna, a partir del uso de instrumentos tecnológicos cada vez más sofisticados, aquellos que refieren constantemente los tres contratistas estadounidenses. Si bien se sugieren algunos proyectos de transformación de las condiciones de vida de la población en conexión con la integración de la Amazonia a las dinámicas políticas y económicas del país, es necesario destacar que los testimonios analizados se centran en el estado perturbador del secuestro en las vidas de los autores como víctimas de la violencia y tienen como objetivo principal, por tanto, denunciar el accionar de las FARC como un grupo que se impone brutalmente sobre la población y el territorio amazónico, sobre todo en los lugares intervenidos socialmente.

Alberto Rangel (Coelho, 2011) y José Eustacio Rivera (Ortiz, 2007), para el caso brasileño y colombiano respectivamente, a través de sus obras de ficción, denuncian las prácticas expoliadoras de recursos naturales por parte de agentes externos a la Amazonia, quienes sólo perseguían su beneficio personal, sin tener en cuenta el daño social que sus acciones generaban. Sin embargo, estos escritores no lograron enunciar una crítica estructurada hacia las elites regionales o nacionales que se beneficiaban económicamente de la dinámica predadora de recursos y la explotación de los colonos y sobre todo, de las poblaciones nativas. En mayor medida, los libros testimoniales del secuestro se concentran en denunciar los vejámenes cometidos por las FARC, principales victimarios, pero dejan traslucir de cierto modo la responsabilidad histórica del Estado frente a la situación de abandono y olvido nacional en que se encuentra la Amazonia colombiana, cuyo potencial ambiental se reitera en términos de disponibilidad de elementos naturales intactos. Aún así la problematización de la región amazónica como frontera donde impera el caos social, en los libros analizados, hace eco del discurso hegemónico que diagnostica las zonas de frontera colombianas como reino del caos y justifica, de ese modo, la imposición de soluciones igualmente violentas, como aquellas que dicen rechazar.

\section{REFERENCIAS}

Alexander, J. (2003). The meanings of social life. A cultural sociology. Oxford, USA: Oxford University Press.

Arruda, A. (2000). Representaciones sociales y cultura en el pensamiento ambientalista brasileño. En: Jodelet, D y Guerrero, A. (Eds.). (2000). Develando la cultura. Estudios en representaciones sociales. México: UNAM.

Betancourt, I. (2012). No hay silencio que no termine. Bogotá, Colombia: Prisa.

Coelho, M. (2011). O sertão amazônico: o inferno de Alberto Rangel. Sociologias, 13 (26), 332-362

Domingues, J. (2003). As dimensões da humanidade em "Infierno Verde", de Alberto Rangel. MOARA, 20, 103-113.

Gonsalves, M.; Stansell, K. y Howes, T. (2009). Lejos del infierno. Una odisea de 1.967 días en manos de las FARC. Bogotá, Colombia: Planeta. 
Guarín, O. (2012). Exploración, ciencia y espectáculo. La cinematografía sobre la Amazonía en la primera mitad del siglo XX. Revista de Antropología Visual, 20, 56-78.

Hoyos, C. (2014). Hermenéutica de la resiliencia en víctimas de secuestro. En el marco de las nuevas concepciones restaurativas. Medellín, Colombia: UNAULA.

Jara, A. (2010). El mundo al revés. Bogotá, Colombia: Norma.

Jaramillo, C. (2016). Amazonia: a laboratory for fiction. Tesis. Universidad de California, Berkeley.

Jimeno, M. (2012). Novelas de la violencia, en busca de una narrativa compartida. En Sierra, R. (Ed.). La restauración conservadora 1946 - 1957. Bogotá, Colombia: Universidad Nacional de Colombia.

Mesnard, P. (2010). Testimonio en resistencia. Buenos Aires, Argentina: Waldhuter.

Ortiz, M. (2007). Mundos en pugna: Narrativas de frontera en la literatura hispanoamericana y brasileña. Tesis. Universidad de Iowa.

Palacio, G. (Ed.). (2001). Naturaleza en disputa. Ensayos de historia ambiental de Colombia 1850-1995. Bogotá, Colombia: Universidad Nacional de Colombia, ICANH.

Pardo, N. (2007) Cómo hacer análisis crítico del discurso. Una perspectiva latinoamericana. Santiago de Chile, Chile: Frasis.

Pinchao, J. F. (2008). Mi fuga hacia la libertad. Bogotá, Colombia: Planeta.

Pineda, R. (2000). Holocausto en el Amazonas. Una historia social de la Casa Arana. Bogotá, Colombia: Planeta.

Pizarro, A. (2009). Amazonía. El río tiene voces. Santiago de Chile, Chile: Fondo de Cultura Económica.
Rodríguez, T. (2007). Sobre el estudio cualitativo de la estructura de las representaciones sociales. En Rodríguez, T. y García, M. (Coord.). Representaciones sociales. Teoría e investigación. Guadalajara: Universidad de Guadalajara.

Rodríguez, T. (2009). Sobre el potencial teórico de las representaciones sociales en el campo de la comunicación. Comunicación y Sociedad. Nueva Época, 11 (enero-junio).

Romero Leal, K. L. (2015). No hay silencio que no termine. Construcción cultural de un campo de literatura testimonial del secuestro. Tesis. Universidad Nacional de Colombia.

Romero Leal, K. L. (2017). Condiciones de producción de un boom de literatura testimonial del secuestro en Colombia. Revista Colombiana de Sociología, 40 (1), 161-186

Ruiz Serna, D. (2015). Gente de monte y otras ponzoñas de la selva. Violencia política y experiencias de lugar en el Pacífico colombiano. Ponencia. XV Congreso de Antropología en Colombia.

Serje, M. (2005). El revés de la nación. Bogotá, Colombia: Uniandes.

Said, E. (2008). Orientalismo. Barcelona, España: Random House Mondadori.

Santoyo, A. A. (2002). Proyecto: representaciones nacionales de la Amazonía colombiana, 1900 - 1975. Una aproximación antropológica e histórica a la retórica y la política de producción de la subjetividad y la naturale$z a$. Tercer Informe. Convocatoria Becas Nacionales 1999.

Santoyo, A. A. (2004). Representaciones y programas de cambio en la Amazonía durante el siglo XIX: análisis del pensamiento civilizador colombiano. En Gasché, J. (Ed.). Crítica de proyectos y proyectos críticos de desarrollo. Una reflexión 
latinoamericana con énfasis en la Amazonía. Iquitos, Perú: Instituto de Investigaciones de la Amazonía Peruana.

Taussig, M. (2002) Chamanismo, colonialismo y el hombre salvaje. Un estudio sobre el terror y la curación. Bogotá, Colombia: Norma.
Vera, H. (2002). Representaciones y clasificaciones colectivas. La teoría sociológica del conocimiento de Durkheim. Revista Sociológica, 50, 103-121. En línea. Recuperado de: http://www.revistasociologica.com.mx/pdf/5005.pdf 